Bolm Inst. oceanogr., S Paulo, $26: 273-283,1977$

\title{
A STUDY OF THE UNDERSAMPLING PROBLEM OF FISH LARVAE OBSERVED AT THE FIXED STATIONS IN SOUTH BRAZIL*
}

\author{
YAS UNOBU MATS UURA
}

Instituto Oceanográfico da Universidade de São Paulo

\section{SYNOPSIS}

The problem of daytime undersampling of larvae observed at two fixed stations made in the spawning ground of the Brazilian sardine is discussed. The size frequency composition of sardine is also discussed.

The predominant species on the stations was the larvae of Sardinella brasiliensis. The larvae of Harengula spp., Scombridae, Bregmacerotidae, Ophidiidae were also collected, but not so abundantly.

When compared to other larvae, the undersampling of sardine larvae during daytime was extremely high. Because the sampling was done both vertically and horizontally at one fixed station and marked undersampling was observed at both stations, it was concluded that the undersampling was caused by avoidance. It was necessary to take this problem into careful consideration for computation of larval abundance.

\section{INTRODUCTION}

One of the purposes of study on early life history of fish is to clarify a relation between the mortality rate during larval stage and the recruitment of fish stock in succeeding years. A prerequisite for a computation of larval abundance is a knowledge of the rate of daytime avoidance of larvae.

* This paper was presented at the CICAR Ichthyoplankton Workshop (UNESCO) 1974, México City. PUBL. NO 372 DO INST. OCEAN. DA USP. 
In calculating the larval abundance and survival rate of the California sardine (Sardinops caemilea) larvae, Ah1strom (1954) revealed that there was a correlation between the undersampling rate and the size of sardine larvae. The regression line fitted to this correlation was used for adjustment of daytime undersampling.

In this paper the daytime undersampling problem of the larvae observed at the two fixed stations made in the spawning ground of the Brazilian sardine, Sardinella brasiliensis (Steindachner, 1879), is discussed and recommendations are given for handling this problem.

\section{MATERIAL AND METHODS}

Twelve series of vertical hauls were made during 24 hours at the fixed station No. 752, labelled $A$, on November 23-24, 1969 (Fig. 1). The station depth was $78 \mathrm{~m}$ and hauls were taken at two hours interval during a 24-hour period at latitude $23^{\circ} 32^{\prime} \mathrm{s}$ and 1ongitude $44^{\circ} 04^{\prime} \mathrm{W}$. The wire length was $70 \mathrm{~m}$ and the average towing velocity was $0.8 \mathrm{~m}$ per second.

Twenty four series of vertical hauls and 23 series of horizontal hauls were made during a 24-hour period at the fixed station No. 1323, or $B$, on January 19-20, 1971 (Fig. 1). The station depth was $65 \mathrm{~m}$. All hauls were spaced at one hour intervals at latitude $24^{\circ} 18^{\prime} \mathrm{S}$ and longitude $45^{\circ} 28^{\prime} \mathrm{W}$. The wire length of vertical hauls was $60 \mathrm{~m}$ and the average towing velocity was $0.8 \mathrm{~m}$ per second. The horizontal hauls were made with a towing velocity of $1.5-2.0$ knots, or from $0.8 \mathrm{~m}$ to $1.0 \mathrm{~m}$ per second in the surface layer.

The net used in sampling was the conical-cylinder plankton net as recommended by UNESCO (1968), which had a mouth diameter of $113 \mathrm{~cm}$ and made of a nylon monofilament gauze of mesh aperture about 420 micra after use. A small flow meter was attached $25 \mathrm{~cm}$ inside of the hoop and three bridles of $150 \mathrm{~cm}$ length were used in front of it. The samples were preserved with a solution of $10 \%$ formalin. Fish eggs and larvae were sorted from plankton samples and for comparative purpose the relative abundance of eggs and larvae per 100 cubic meters of water strained was calculated.

The larvae collected were classified to family level with exception to Pleuronectiformes and Anguilliformes (Leptocephali), which were classified 


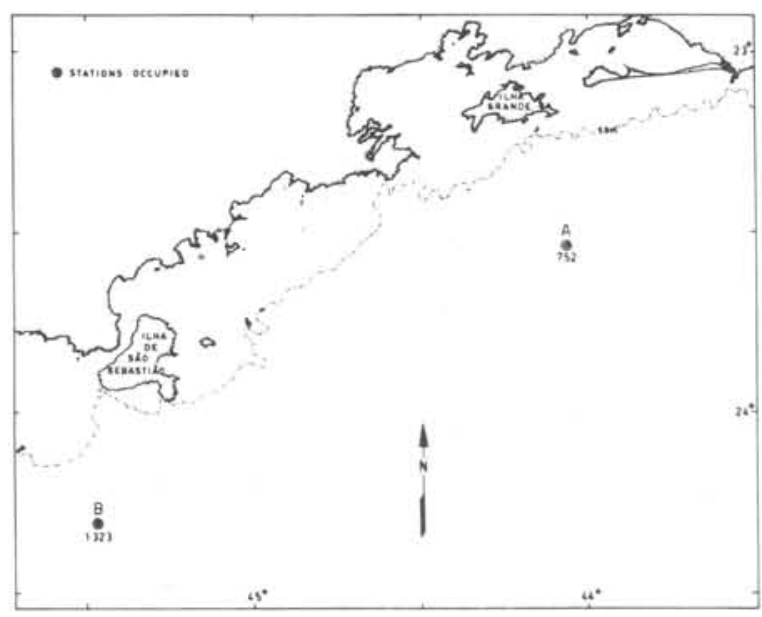

Fig. 1 - Location of fixed stations $A$ and $B$.

only to order level. The predominant groups were identified to species and the percentage contribution of each determined.

At station $A$, all specimens except disintegrated larvae were measured and grouped by $0.5 \mathrm{~mm}$ intervals. At station $B$, because the collections contained so many larvae which showed monomodal distribution, we measured circa 100 specimens picked up at random from each sample. The number of larvae at each size class was calculated and shown in percent. Since only few specimens were collected during daytime, a comparison of the size composition of night and day haul series is less important. Therefore only the size frequency of night-caught larvae was shown in Figure 5.

Fixed station data was taken by the R/V "Prof. W. Besnard" of the Instituto Oceanogräfico da Universidade de São Paulo. I wish to thank Captain Adilson Gama and the crew of the vessel for collection of material at sea and the staff members of the Instituto Oceanográfico for laboratory works. Special thanks are due to Dr. E.H. Ahlstrom of the National Marine Fisheries Service and Dr. S. A. Antunes of the Instituto Oceanográfico for critical reading and revision of the manuscript.

\section{RESULTS}

- OCCURRENCE OF FISH LARVAE AT THE FIXED STATIONS

Abundance of the groups at each haul is shown in Tables I, II and III. Total counts for each species are given in Table IV. 
TABLE I- Occurrence of $\mathrm{fish}$ larvae at station $A$ in November 1969 (vertical hauls)

\begin{tabular}{|c|c|c|c|c|c|c|c|c|c|c|c|c|c|}
\hline Sample number & 257 & 258 & 259 & 260 & 261 & 262 & 263 & 264 & 265 & 266 & 267 & 268 & \multirow{2}{*}{ Total } \\
\hline Family $\longrightarrow$ Time & $18: 40$ & $20: 40$ & $22: 40$ & $00: 40$ & $02: 40$ & $04: 40$ & $06: 40$ & $08: 40$ & $10: 40$ & $12: 40$ & $14: 40$ & $16: 40$ & \\
\hline Clupeidae & 319 & 74 & 437 & 522 & 53 & 137 & 49 & 2 & 0 & 2 & 0 & 0 & 1595 \\
\hline Engraulidae & 1 & 0 & 0 & 3 & 0 & 0 & 0 & 0 & 0 & 0 & 0 & 0 & 4 \\
\hline Scombridae & 1 & 0 & 0 & 1 & 0 & 0 & 0 & 0 & 0 & 0 & 0 & 0 & 2 \\
\hline Bregmacerotidae & 5 & 13 & 36 & 55 & 26 & 12 & 21 & 21 & 24 & 40 & 40 & 8 & 301 \\
\hline Sphyraenidae & 0 & 0 & 0 & 0 & 0 & 0 & 0 & 0 & 0 & 0 & 0 & 0 & 0 \\
\hline Ophidiidae & 3 & 3 & 6 & 15 & 10 & 0 & 4 & 3 & 2 & 2 & 6 & 1 & 55 \\
\hline Pleuronectiformes & 1 & 1 & 3 & 4 & 2 & 1 & 0 & 1 & 0 & 1 & 1 & 0 & 15 \\
\hline Gerridae & 1 & 0 & 0 & 0 & 0 & 0 & 0 & 0 & 0 & 0 & 0 & 0 & 1 \\
\hline Synodontidae & 1 & 1 & 3 & 2 & 4 & 2 & 1 & 4 & 2 & 0 & 2 & 2 & 24 \\
\hline Balistidae & 0 & 0 & 0 & 0 & 0 & 0 & 0 & 0 & 0 & 0 & 0 & 0 & 0 \\
\hline Leptocephalus & 0 & 0 & 0 & 0 & 0 & 0 & 0 & 0 & 0 & 0 & 0 & 0 & 0 \\
\hline Gonos tomatidae & 0 & 0 & 0 & 0 & 0 & 0 & 0 & 0 & 0 & 0 & 0 & 0 & 0 \\
\hline Carangidae & 5 & 0 & 0 & 2 & 1 & 0 & 1 & 0 & 0 & 0 & 1 & 0 & 10 \\
\hline Gobiidae & 1 & 1 & 4 & 3 & 1 & 1 & 0 & 0 & 0 & 0 & 0 & 0 & 11 \\
\hline Exocoetidae & 0 & 0 & 0 & 0 & 0 & 0 & 0 & 0 & 0 & 0 & 0 & 0 & 0 \\
\hline Serranidae & 0 & 0 & 0 & 1 & 1 & 0 & 0 & 1 & 0 & 0 & 0 & 0 & 3 \\
\hline Triglidae & 0 & 0 & 0 & 0 & 0 & 0 & 0 & 0 & 0 & 0 & 0 & 0 & 0 \\
\hline Mugilidae & 0 & 1 & 0 & 0 & 0 & 0 & 0 & 0 & 0 & 0 & 0 & 0 & 1 \\
\hline Lophiidae & 0 & 0 & 1 & 0 & 1 & 0 & 0 & 0 & 0 & 0 & 0 & 0 & 2 \\
\hline Others & 17 & 11 & 22 & 22 & 11 & 4 & 13 & 11 & 0 & 0 & 3 & 2 & 116 \\
\hline Total & 355 & 105 & 512 & 630 & 110 & 157 & 89 & 43 & 28 & 45 & 53 & 13 & 2140 \\
\hline
\end{tabular}

TABLE II - Occurrence of fish larvae at station B in January 1971 (vertical hauls)

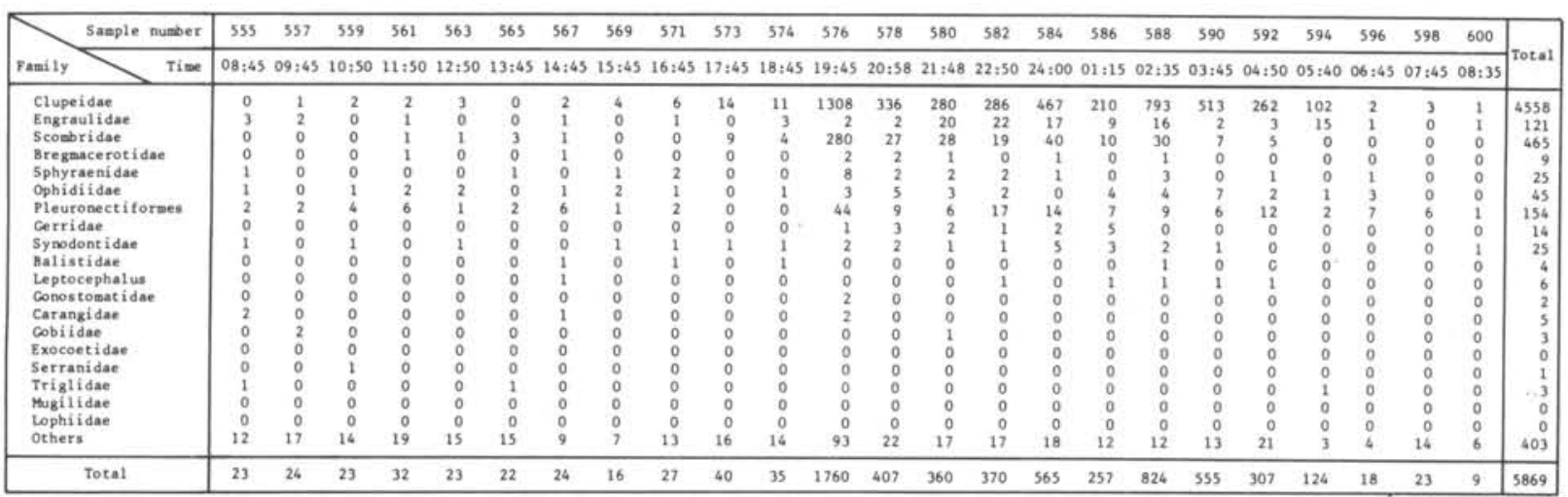

TABLE III-Occurrence of $\mathrm{fish}$ larvae at station B in January 1971 (horizontal hauls)

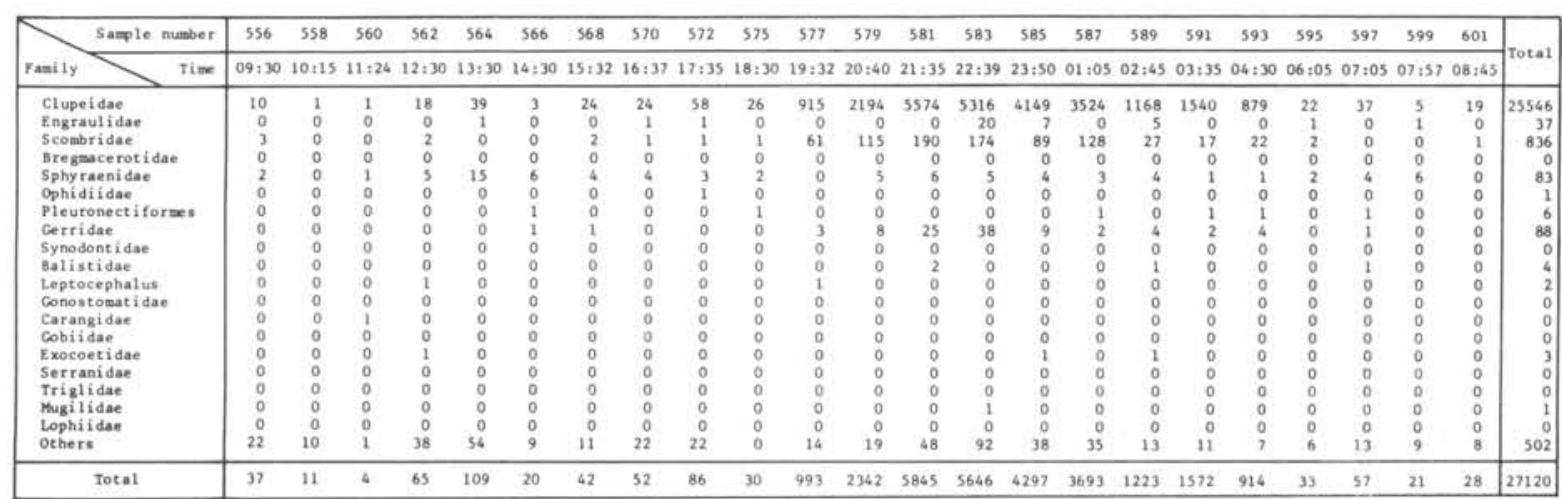


TABLE IV - Comparison of abundance of fish larvae collected at the fixed stations

\begin{tabular}{|c|c|c|c|c|c|c|c|c|c|}
\hline \multirow{3}{*}{ Species } & \multicolumn{3}{|c|}{ Cruise November 1969 (St.A) } & \multicolumn{6}{|c|}{ Cruise January 1971 (St. B) } \\
\hline & \multicolumn{3}{|c|}{ Vertical hauls } & \multicolumn{3}{|c|}{ Vertical hauls } & \multicolumn{3}{|c|}{ Horizontal hauls } \\
\hline & $\begin{array}{c}\text { Fish larvae } \\
\text { collected }\end{array}$ & $\begin{array}{l}\text { Percent } \\
\text { of total }\end{array}$ & Rank & $\begin{array}{c}\text { Fish 1arvae } \\
\text { collected }\end{array}$ & $\begin{array}{l}\text { Percent } \\
\text { of total }\end{array}$ & Rank & $\begin{array}{c}\text { Fish larvae } \\
\text { collected }\end{array}$ & $\begin{array}{l}\text { Percent } \\
\text { of total }\end{array}$ & Rank \\
\hline Sardinella brasiliensis & 1595 & 74.5 & 1 & 4345 & 74.1 & 1 & 24296 & 89.6 & 1 \\
\hline Harengula spp. & 0 & 0 & - & 213 & 3.6 & 3 & 1250 & 4.6 & 2 \\
\hline Bregmaceros atianticus & 301 & 14.0 & 2 & 9 & 0.2 & 11 & 0 & 0 & - \\
\hline Euthynnus alletteratus & 0 & 0 & - & 146 & 2.5 & 5 & 231 & 0.9 & 4 \\
\hline Other scombrids* & 2 & 0.1 & 10 & 305 & 5.2 & 2 & 605 & 2.2 & 3 \\
\hline Engraulidae & 4 & 0.2 & 9 & 121 & 2.1 & 6 & 37 & 0.1 & 7 \\
\hline Pleuronectiformes & 15 & 0.7 & 5 & 166 & 2.8 & 4 & 6 & 0.02 & 8 \\
\hline Ophidiidae & 55 & 2.6 & 3 & 45 & 0.8 & 7 & 1 & 0.003 & - \\
\hline All others & 168 & 7.9 & - & 514 & 8.7 & - & 694 & 2.6 & - \\
\hline Tota1 & 2140 & 100.0 & & 5869 & 100.0 & & 27120 & 100.0 & \\
\hline
\end{tabular}

Sardinella brasiliensis larvae were predominant and contributed $74.5 \%$ of total larvae collected at station $A$ and $74.1 \%$ and $89.6 \%$, respectively for vertical and horizontal hauls at station $B$.

Concerning other species, the occurrence patterns at the two stations were somewhat different. At station $A$ the second predominant species was Bregmaceros atlanticus (Goode \& Bean, 1886) larvae, followed by the groups of Ophidiidae, Synodontidae and Pleuronectiformes in this sequence. At station $B$ the second predominant species in vertical hauls was the group of Scombridae, followed by Harengula spp. ${ }^{1}$ and Pleuronectiformes. In horizontal hauls Harengula spp. ranked second and then Scombridae, Gerreidae, Sphyraenidae and Engraulidae followed in order of abundance.

Comparing the occurrence of fish larvae in vertical and horizontal hauls at station $B$, we can notice that sardine larvae were collected more abundantly in surface horizontal hauls. On the other hand the larvae of Harengula species were collected more abundantly in vertical hauls $(4.6 \%)$ than in horizontal hauls $(3.6 \%)$.

1 Two Harengula species occur in south Brazilian waters, i.e. H. jaguana and H. clupeola. A key for identification of the two species (Whitehead, 1973) cannot be used for larvae. 


\section{- UNDERSAMPLING PROBLEM}

The occurrence of sardine larvae and others are shown in Figures 2, 3 and 4. Almost all sardine were collected from night hauls at both stations. The difference between night and day catches was so great that we could not compare the distribution of sardine larvae caught by day and by night. The night/day catch ratio of larvae is presented in Table $\mathrm{V}$.

The night/day catch ratio at station $A$ was 32.4 for sardine larvae and 2.3 for others. Second ranked species, Bregmaceros atlanticus, showed 1ittle difference between day and night catches inasmuch as the night/day catch ratio was only 1.03 .
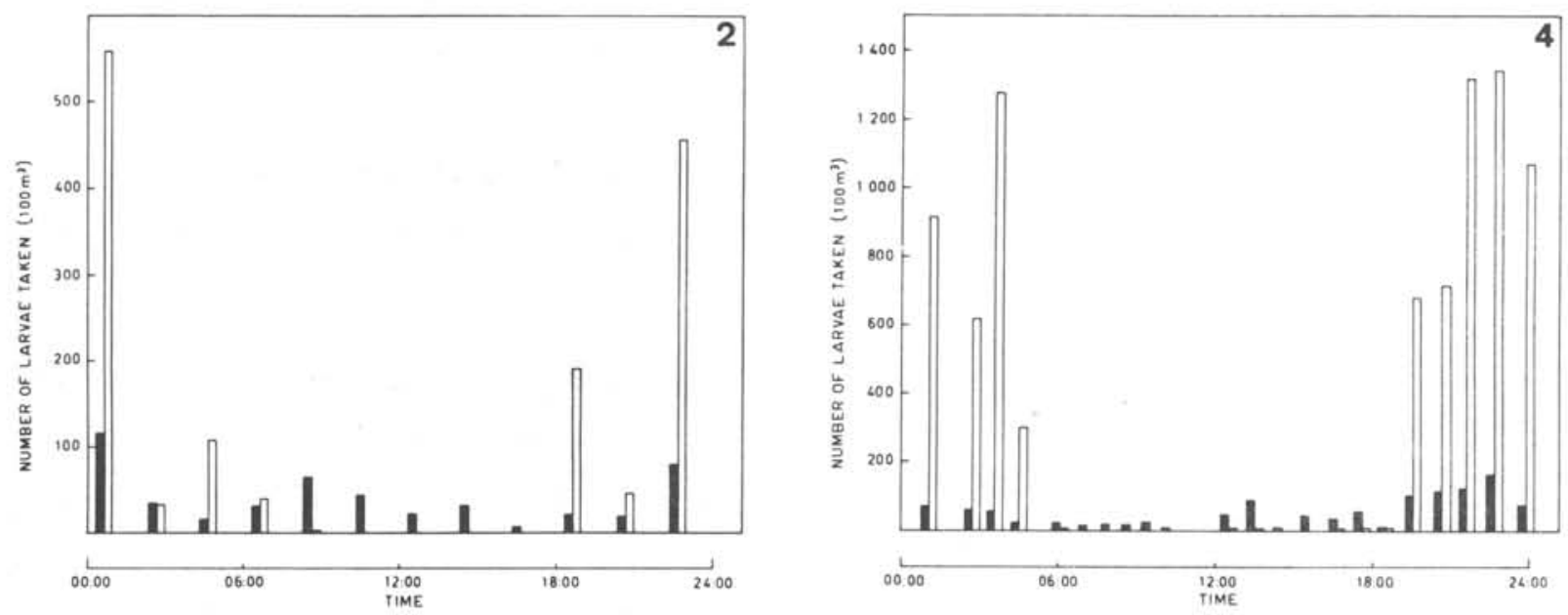

Fig. 2-Diurnal change of occurrence of sardine larvae (white column) and all other larvae (black col umn), observed at the fixed station $A$ in November 23-24, 1969. VERTICAL HAULS.

Fig. 3-Diurnal change of occurrence of sardine larvae (white column) and all other larvae (black column), observed at the fixed station $B$ in January 19-20, 1971. VERTICAL HAULS.

Fig. 4-Diurnal change of occurrence of sardine larvae (white column) and all other larvae (black column), observed at the fixed station $B$ in January 19-20, 1971. HORIZONTAL HAULS. 


\begin{tabular}{|c|c|c|c|c|c|c|c|c|c|}
\hline \multirow{3}{*}{ Species } & \multirow{2}{*}{\multicolumn{3}{|c|}{$\begin{array}{c}\begin{array}{c}\text { Station A } \\
\text { (November 1969) }\end{array} \\
\text { Vertical haul } \\
\end{array}$}} & \multicolumn{6}{|c|}{$\begin{array}{c}\text { Station o } \\
\text { (Jatuary 1971) }\end{array}$} \\
\hline & & & & \multicolumn{3}{|c|}{ Vertical haul } & \multicolumn{3}{|c|}{ Horizontal haul } \\
\hline & Day & Night & $N / D^{1}$ & Day & sight & $\mathrm{s} / \mathrm{D}$ & Day & Nighte & $N / D$ \\
\hline Sandinella bravitienvis & 7.2 & 233.5 & 32.4 & 0.6 & 392.5 & 615.2 & 1.7 & 826.3 & 486.1 \\
\hline Harengula app. & 0 & 0 & - & 3.9 & 14.7 & 3.8 & 10.6 & 34.3 & 3.2 \\
\hline Euthernual al letterat ue & 0 & 0 & - & 0.5 & 7.1 & 15.1 & 0 & 7.7 & - \\
\hline Brepmaceroe atlantion & 22.4 & 21.8 & 1.03 & 0.2 & 0.7 & 3.1 & 0 & 0 & - \\
\hline All others & 11.6 & 26.6 & 2.3 & 29.4 & 68.2 & 2.3 & 17.1 & 35.8 & 2.1 \\
\hline A11 larvase & 41.2 & 281.7 & 6.8 & 36.6 & 483.2 & 14.0 & 29.4 & 904.1 & 30.4 \\
\hline Nunber of hauls ${ }^{2}$ & 6 & 6 & & 13 & 11 & & 13 & 10 & \\
\hline \multicolumn{10}{|c|}{ 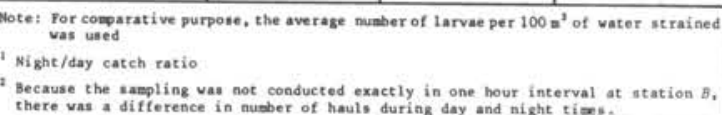 } \\
\hline
\end{tabular}

TABLE V - Diurnal differences in average number of fish larvae collected at the fixed stations, $A$ and $B$

At station $B$ the night/day catch ratio was 615.2 for sardine larvae in vertical hauls and 486.1 in horizontal hauls. Harengula spp. showed the night/day catch ratio of 3.8 and 3.2 , respectively in vertical and horizontal hauls. Euthynnus alletteratus (Rafinesque, 1810) showed the night/day catch ratio of 15.1 in vertical hauls, whereas in horizontal hauls it was not collected in daytime hauls. The ratio obtained for other species were 2.3 and 2.1 , respectively in vertical and horizontal hauls.

Comparing the night/day catch ratio of sardine larvae with those given by other authors (generally less than 10) our values were extremely high. Since only sardine larvae showed such elevated values at fixed stations, we cannot assume that the sampling method was inadequate.

\section{- SIZE FREQUENCY OF SARDINE LARVAE}

Table VI shows a comparison of the size frequency composition between day and night catches at two stations. The size frequency of night-caught sardine larvae collected at the fixed stations is shown in Figure 5 .

At station $A$ a bimodal size frequency was observed, i.e. a small-size group with average length $6.3 \mathrm{~mm}$, ranging from 4.0 to $8.5 \mathrm{~mm}$ and a 1 arge-size group with average length $12.5 \mathrm{~mm}$, ranging from 9.0 to $16.5 \mathrm{~mm}$. The number of larvae was 1378 for the former and 146 for the latter. We may assume that these two groups were derived from different spawning periods.

A difference in size frequency of sardine larvae collected from vertical and horizontal hauls at station $B$ was not observed. This suggests that the size composition of sardine larvae is the same in upper and deeper layers. 
TABLE VI - Size frequency composition of sardine larvae taken at two fixed stations

\begin{tabular}{|c|c|c|c|c|c|c|}
\hline \multirow{3}{*}{$\begin{array}{l}\text { Size } \\
\text { class } \\
(\operatorname{mm})\end{array}$} & \multirow{2}{*}{\multicolumn{2}{|c|}{$\frac{\text { Station } A}{\text { Vertical haul }}$}} & \multicolumn{4}{|c|}{ Station $B$} \\
\hline & & & \multicolumn{2}{|c|}{ Vertical haul } & \multicolumn{2}{|c|}{ Horizontal haul } \\
\hline & Day & Night & Day & Night & Day & Night \\
\hline 3.25 & & & & 1 & & \\
\hline 3.75 & & & 1 & 5 & 3 & \\
\hline 4.25 & & 2 & 1 & 4 & 1 & 4 \\
\hline 4.75 & & 12 & 0 & 5 & 1 & 53 \\
\hline 5.25 & 2 & 113 & 0 & 6 & 0 & 141 \\
\hline 5.75 & 7 & 222 & 0 & 26 & 2 & 315 \\
\hline 6.25 & 29 & 454 & 1 & 64 & 1 & 553 \\
\hline 6.75 & 11 & 455 & 0 & 67 & 4 & 378 \\
\hline 7.25 & 2 & 110 & 0 & -51 & 2 & 122 \\
\hline 7.75 & 0 & 9 & 0 & 80 & 2 & 610 \\
\hline 8.25 & 1 & 1 & 1 & 164 & 2 & 1089 \\
\hline 8.75 & & 0 & 0 & 417 & 2 & 2289 \\
\hline 9.25 & & 1 & 0 & 835 & 5 & 4126 \\
\hline 9.75 & & 1 & 1 & 781 & 4 & 5332 \\
\hline 10.25 & & 2 & 0 & 752 & 3 & 3977 \\
\hline 10.75 & & 10 & 1 & 400 & 5 & 2476 \\
\hline 11.25 & & 12 & & 285 & 1 & 1254 \\
\hline 11.75 & & 21 & & 184 & 1 & 561 \\
\hline 12.25 & & 25 & & 55 & 1 & 143 \\
\hline 12.75 & & 31 & & 20 & & 157 \\
\hline 13.25 & & 19 & & 8 & & 103 \\
\hline 13.75 & & 13 & & 3 & & 50 \\
\hline 14.25 & & 6 & & 11 & & 103 \\
\hline 14.75 & & 3 & & 5 & & 103 \\
\hline 15.25 & & 0 & & 5 & & 50 \\
\hline 15.75 & & 0 & & 1 & & \\
\hline 16.25 & & 2 & & 0 & & \\
\hline 16.75 & & & & 1 & & \\
\hline Total & 52 & 1524 & 6 & 4236 & 40 & 23989 \\
\hline
\end{tabular}

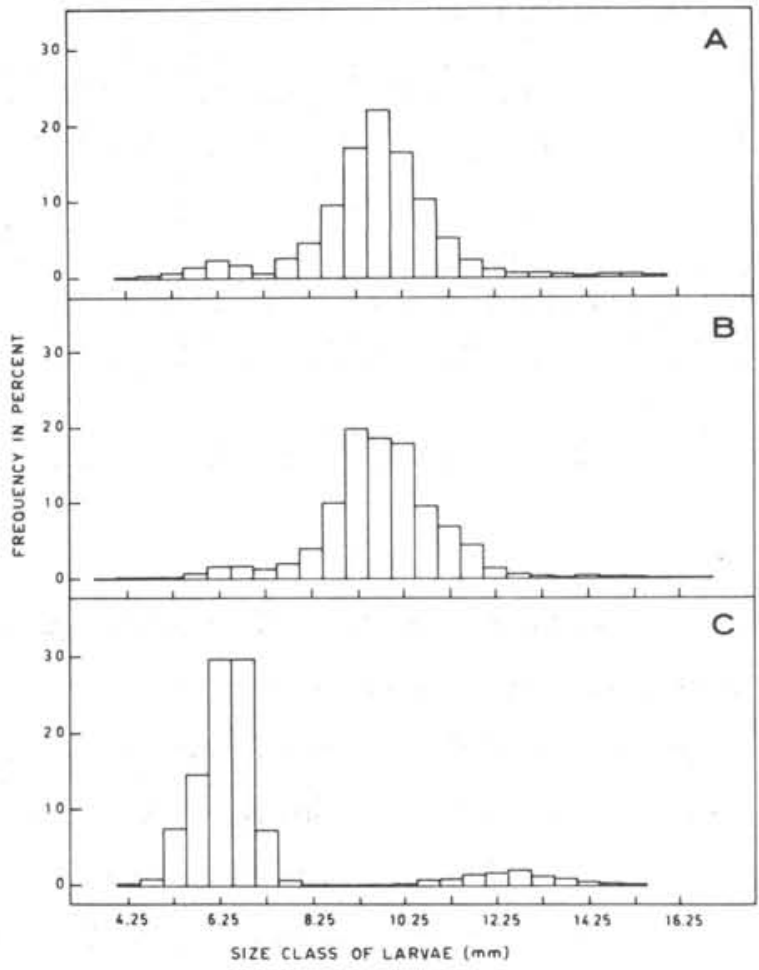

Fig. 5-Size frequency composition of night-caught sardine larvae. A: station $B$ (horizontal hauls) B: station $B$ (vertical hauls) C: station $A$ (vertical hauls)

\section{DISCUSSION}

The undersampling problem of fish larvae during daytime, especially when used small size and low speed sampling gear, is well known. Clutter \& Anraku (1968) summarized the undersampling of zooplankton by avoidance.

Concerning clupeid larvae, the undersampling problem has been discussed by many workers, as summarized in Table VII. From this Table we can notice that the night/day catch ratio of the Brazilian sardine larvae at the fixed stations was extremely ligh. What factors might cause such marked undersampling during daytime? We can reject an hypothesis of diurnal vertical migration of sardine larvae, since the undersampling was observed both in vertical and horizontal hauls. There remains a possibility that the sampling was not made in the same water mass during daytime and the clumping of sardine larvae caused the apparent undersampling at the fixed stations. This is 
less probable inasmuch as similar undersampling was observed at both fixed stations and these were occupied in different places and times. Futhermore the occurrence of fish eggs at two fixed stations showed that there were no distinct difference between day and night time samples ${ }^{2}$.

Avoidance may be the main cause of this phenomenon. Clutter \& Anraku (1968) considered various factors which could cause avoidance of zooplankton, i.e. pressure acceleration, visual, acoustic and light effects. It is very difficult to know which factors affected the avoidance of the Brazilian sardine larvae.

TABLE VII - Comparison of the night/day catch ratio of clupeid larvae observed by various authors

\begin{tabular}{|c|c|c|c|c|}
\hline Authors & Sampling gears & Species & $\mathrm{N} / \mathrm{D}^{1}$ & Period of observations \\
\hline Wallace (1924) & Peterson young fish trawl & Clupea harengue & 3.2 & $1921-23$ \\
\hline Russe1 (1926\& $\&$ 28) & 2 m stramin ring traw 1 & Sardina pilchardus & $5.7-13.9$ & $1924-26$ \\
\hline Silliman $(1943)^{2}$ & Closing net & Sardinops caerulea & $4 \cdot 1$ & $1931 \& 41$ \\
\hline Ah1strom (1954) & $1 \mathrm{~m}$ standard net & Sardinops caemulea & 6.5 & $1940,41,50 \& 51$ \\
\hline Bridger (1956) & Helgoland larva net & Clupea harengus & 6.3 & $1952-53$ \\
\hline Bridger (1956) & Helgol and larva net & Sardina pilcharcus & 4.1 & $1952-53$ \\
\hline Bridger (1958) & Gulf-III net & Clupea harengus & $0.7-1.1$ & $1955-56$ \\
\hline Ahlstrom $(1959)^{2}$ & Closing net & Sardinops caemilea & 3.9 & $1941,50 \& 51$ \\
\hline Ahlstrom (1965) & $1 \mathrm{~m} s t a n d a r d$ net & Sardinops caemulea & 6.4 & $1950-58$ \\
\hline Present author ${ }^{2}$ & $1.13 \mathrm{~m}$ conical-cylinder net & Sardinella brasiliensis & 32.4 & 1969 (station $A$ ) \\
\hline Present author ${ }^{2}$ & $1.13 \mathrm{~m}$ conical-cylinder net & Sardinella brasiliensis & 615.2 & 1971 (station $B$ ) \\
\hline $\begin{array}{l}\text { Present author }{ }^{3} \\
\text { (in preparation) }\end{array}$ & 1.13 m conical-cylinder net & Sardinella brasiliensis & 3.3 & $1969-71$ \\
\hline \multicolumn{5}{|c|}{$\begin{array}{l}{ }^{1} \text { Night/day catch ratio } \\
2 \text { Observation at fixed station } \\
{ }^{3} \text { Night/day catch ratiowas calculated using the average number of sardine larvae (per } 100 \mathrm{~m}^{3} \text { of water strained) } \\
\text { taken at positive stations on the cruises of } 1969 \text { through } 1971 \text {. }\end{array}$} \\
\hline
\end{tabular}

2 The author failed to identify any of fish eggs taken at two fixed stations. In order to see a variation of occurrence of fish eggs during day and night times, a type of fish egg was chosen as an indicator of water mass and named type III-D egg. Averages of occurrences of III-D eggs in percent of total eggs were $7.6 \%$ and $12.3 \%$, respectively in night-caught and day-caught samples at station $A$, and $25.0 \%$ and $23.5 \%$, respectively in night-caught and day-caught samples from vertical hauls at station $B$. This fact seems to prove that the same water mass has been sampled during day and night times. Notwithstanding the fact mentioned above, it is possible, if not certain, that occasional expections occur, suggesting that an areal concentration of sardine larvae has happened during night. 
Analysing the plankton samples from the CalCOFI investigations, Isaacs (1964) concluded that the abundance of sardine larvae taken during daytime coincided with that of the mortality of night time samples. He suggested that the daytime sampler might act as predator for sardine larvae which caught only weaker or less alert larvae.

Because an occurrence of only few sardine larvae during daytime was observed at the fixed stations, it is not adequate to adjust the daytime samples with the ratio of night/day catches. Therefore the samples collected during daytime should not be used for computation of larval abundance, at least wher used the same sampling gear.

\section{RESUMO}

Um dos objetivos do estudo quantitativo do ictioplâncton é esclarecer a relação entre a mortalidade de larvas e o recrutamento do estoque nos anos sucessivos.

Para computar a abundância de larvas é necessário obter as informações sobre a eficiência da captura. Dois fatores tẽm que ser considerados: um, o escape de larvas pequenas através da malha da rede e, outro, a "avoidance" de larvas maiores durante o dia.

Este trabalho apresenta as observações feitas sobre a variação diurna de ocorrência de larvas de peixes, realizadas em 1969 e 1971 em duas estações fixas localizadas no sul do Brasil.

As larvas mais abundantes pertenciam a Sardinella brasiliensis. Outras que predominaram foram: Bregmaceros atlanticus, Euthynnus alletteratus e Harengula spp. Foram observadas coletas mais abundantes de larvas de sardinha na camada superior.

As larvas de sardinha foram coletadas principalmente durante a noite. o "undersampling" foi considerado devido à "avoidance". A razão entre capturas médias durante a noite e o dia foi tão grande que é preciso uma consideração sobre ofator de "avoidance" das larvas de sardinha para a computação de abundância do mesmo. 


\section{REFERENCES}

AHLSTROM, E. H. 1954. Distribution and abundance of egg and larval populations of the Pacific sardine. Fishery Bull. Fish Wildl. Serv. U.S., $56(93): 83-140$.

1959. Vertical distribution of pelagic fish eggs and larvae off California and Baja California. Fishery Bull. Fish Wildl. Serv. U.S., 60(161):107-146.

1965. A review of the effects of the environment of the Pacific sardine. Spec. Publs int. Comn. NW. Atlant. Fish., (6):53-74.

BRIDGER, J. P. 1956. On day and night variation in catches of fish larvae. J. Cons. perm. int. Explor. Mer, 22(1):42-57.

1958. On efficiency tests made with a modified Gulf III high-speed tow net. J. Cons. perm. int. Explor. Mer, 23(3):357-365.

CLUTTER, R. I. \& ANRAKU, M. 1968. Avoidance of samplers. In: Zooplankton sampling. Monogr. oceanogr. Methodo1., (2):57-76.

ISAACS, J. D. 1964. Night-caught and day-caught larvae of the California sardine. Science, N.Y., 144(3622):1132-1133.

RUSSEL, F. S. 1926. The vertical distribution of marine macroplankton. 3. Diurnal observations on the pelagic young of teleostean fishes in the P1ymouth area. J. mar. bio1. Ass. U. K., 14:387-414.

1928. The vertical distribution of marine macroplankton. 8. Further observations on the diurnal behaviour of the pelagic young of teleostean fishes in the Plymouth area. J. mar. biol. Ass. U. K., 15: 829-850.

SILLIMAN, R. P. 1943. Studies on the Pacific pilchard or sardine (Sardinops caerulea). 6. Thermal and diurnal changes in the vertical distribution of eggs and larvae. Spec. Scient. Rep., U. S. Fish Wildl. Serv., (22):1-17.

UNESCO. 1968. Reports of ICES SCOR-UNESCO Symposium of hydrodynamics of plankton samplers and the meeting of working party 3 . In: Zooplankton sampling. Monogr. oceanogr. Methodo1., (2):160-163.

WALLACE, W. 1924. First report on young herring in the southern North sea and English channel. Part 1. Distribution and growth of 1 arval and post-1arval stages. Fishery Invest., Lond., Ser. II, 7(4).

WHITEHEAD, P. J. P. 1973. The clupeid fishes of the Guianas. Bu11. $\mathrm{Br}$. Mus . nat. Hist., Zoo1., 25(supp1. 5):1-227.

(Received March 25, 1976) 